\author{
Aleksandra Walczak \\ (D) https://orcid.org/0000-0001-7288-0703 \\ Marcin Kozak \\ (D) https://orcid.org/0000-0002-8426-6257
}

\title{
Mobbing w organizacji pomocowej jako przykład patologii zarządzania Studium przypadku
}

\begin{abstract}
Mobbing is one of the examples of pathology in organization management. In the article, we presented the problem in the perspective of organizational games using the technique of participant observation. The article is not intended to stigmatize the help facility, but to show mobbing as a significant and difficult problem for the victim. It has destructive effects and is difficult to identify and prevent. The authors believe that the article will help to pay attention to the essence of the problem and to notice negative effect.
\end{abstract}

Key words: mobbing, pathology, social role, retirement home

\section{Wprowadzenie}

Niejednokrotnie jako jedną z głównych metafor wykorzystywanych do analizy społeczeństwa stosujemy metaforę organizmu. Jest to jedna $\mathrm{z}$ istotniejszych teorii, z którą spotyka się student socjologii na pierwszym roku swojej drogi akademickiej. Te koncepcje nie były obce już Platonowi czy Arystotelesowi, lecz odwoływały się do nich także idee chrześcijańskie czy późniejsze, pokazujące złożoność życia społecznego (Szacki, 2006, s. 40). Dlaczego w prezentowanym szkicu warto się odwołać do tej koncepcji? W życiu codziennym — niejednokrotnie nie zdając sobie z tego sprawy - jesteśmy zaplątani w sieć wielu działań, które z kolei wiążą się z odpowiednim funkcjonowaniem komórek, w których żyjemy: 
czy to rodzina, czy praca zawodowa, czy kółko zainteresowań, czy działanie na rzecz społeczności lokalnej. Słowem, pełnimy różne role społeczne, względem których możemy mówić o pewnym zespole oczekiwań wobec konkretnych osób, instytucji, gdzie spełniamy obowiązki (Sztompka, 2010, s. 29). Gdy mówimy o zjawisku mobbingu, to należy mieć świadomość, że to nie jest tylko i wyłącznie sprawa personalna, problem wokół konkretnej jednostki (choć przede wszystkim jej to dotyczy), lecz wokół całej organizacji, wokół jej pracowników i - w przypadku domu pomocy społecznej — również beneficjentów, podopiecznych, o czym się przekonamy.

\section{Organizacje pomocowe i zasady ich funkcjonowania}

Zanim przejdziemy do sedna, a mianowicie do omówienia kwestii mobbingu, warto przytoczyć kilka informacji na temat funkcjonowania pomocy społecznej w Polsce, a następnie przedstawić różnice między organizacjami gospodarczymi a pomocowymi. Ma to na celu usystematyzowanie wiedzy, która choć - z uwagi na ramy treściowe - nie będzie nazbyt rozszerzona, pozwoli spojrzeć nań w sposób całościowy, systemowy. Zasady funkcjonowania pomocy społecznej określiła uchwalona 29 listopada 1990 roku ustawa o pomocy społecznej, a celem działań stała się pomoc wszystkim osobom i rodzinom, które same nie są w stanie przezwyciężyć trudności życiowych. Jedną z form działania staje się po raz pierwszy ustawowo zapisana praca socjalna. Partnerem ośrodków pomocy społecznej stały się wojewódzkie zespoły pomocy społecznej, będące agendami rządowymi, a do ich zadań należały m.in.: analiza potrzeb, organizacja, finansowanie i kierowanie do placówek pomocy instytucjonalnej, wspieranie organizacji pozarządowych i funkcje kształceniowe (K rzyszkow ski, 2010, s. 25). Zdajemy sobie oczywiście sprawę z tych kwestii, które determinują zapotrzebowanie na pomoc społeczną: może to być na przykład starzenie się społeczeństwa, pauperyzacja regionów, wybranych grup społecznych. I w tym miejscu warto postawić pytanie: jaką drogą podążać, aby efektywnie przeciwdziałać negatywnym skutkom tych zjawisk? Tu z pomocą przychodzą organizacje pozarządowe, które powinny stać się naturalnym partnerem władzy lokalnej i obywatela w rozwiązywaniu problemów (Krzyszkow ski, 2010, s. 27). Z własnego doświadczenia możemy również dodać, że istotną kwestią jest kadra pomocy społecznej i nie chodzi o zakres profesjonalizmu czy umiejętności posiadanych przez pracowników socjalnych bądź inne osoby nastawione na działania pomocowe. Sami pracownicy socjalni — jak podaje Magdalena Dudkiewicz - są przekonani o negatywnym ich obrazie, kojarzeni są bowiem z pomagającą „darmozjadom" grupą zawodową, która marnuje publiczne pieniądze (Dudkiewicz, 2012, s. 126). Nietrudno zatem wywnioskować, że negatywny obraz przekłada się na relacje ze społeczeństwem, zaś same osoby korzystające

$184 \mathrm{z}$ usług pomocowych nadal są poddawane stygmatyzacji, pejoratywnej ocenie 
nadbudowanej wokół skojarzeń o nieporadności czy lenistwie. Nie zmienia to oczywiście faktu, że potrzeba doszkalania personelu pomocy społecznej jest ogromna, a zasoby z tych przedsięwzięć mogą przynosić owoce w postaci nie tylko zwiększonej profesjonalizacji, lecz także pomocy jednostkom tego potrzebującym.

Za Krzyszkowskim warto również przytoczyć różnice, jakie dzielą organizacje rynkowe i pomocowe (Krzyszkowski, 2010, s. 29-31).

Tabela 1

Różnice między organizacjami rynkowymi i pomocowymi

\begin{tabular}{|c|c|}
\hline Organizacje rynkowe & Organizacje pomocowe \\
\hline \multicolumn{2}{|c|}{ Cel działania } \\
\hline $\begin{array}{l}\text { Zysk, samodzielność wypracowania środków } \\
\text { finansowych, działalność związana z produkcją } \\
\text { i dystrybucją przedmiotów oraz usług }\end{array}$ & $\begin{array}{l}\text { Udzielanie pomocy potrzebującym, zależność } \\
\text { od dotacji i środków finansowych uzyskanych } \\
\text { od państwa i gminy, działalność wielopłaszczyz- } \\
\text { nowa, dotycząca różnorodnych problemów }\end{array}$ \\
\hline \multicolumn{2}{|c|}{ Klienci organizacji } \\
\hline $\begin{array}{l}\text { Zgłaszają sie z własnej woli, kierując się chęcią } \\
\text { posiadania produktu, poprawą standardu życio- } \\
\text { wego, dysponują środkami finansowymi, mają } \\
\text { konkretne potrzeby i są mało zróżnicowani }\end{array}$ & $\begin{array}{l}\text { Sytuacja życiowa zmusza do zgłoszenia się do } \\
\text { organizacji, mają poczucie deprywacji lub pre- } \\
\text { zentują postawy roszczeniowe, są niezaradni } \\
\text { życiowo i bardzo zróżnicowani społecznie i pod } \\
\text { względem potrzeb }\end{array}$ \\
\hline \multicolumn{2}{|c|}{ Efekt działania } \\
\hline $\begin{array}{l}\text { Szybko widoczny i wymierny efekt, zadowole- } \\
\text { nie można określić na podstawie popytu na dany } \\
\text { towar, zaś usługi i produkty mają z reguły po- } \\
\text { dobny charakter }\end{array}$ & $\begin{array}{l}\text { Efekt jest niewymierny, trudny do sprawdzenia, } \\
\text { zaś klienci rzadko okazują wdzięczność, a usłu- } \\
\text { gi należą do wielopłaszczyznowych, skupionych } \\
\text { na rozmaitych potrzebach }\end{array}$ \\
\hline \multicolumn{2}{|c|}{ Personel } \\
\hline $\begin{array}{l}\text { Stres personelu związany jest z wymaganiami } \\
\text { klienta dotyczącymi jakości usług czy towarów } \\
\text { dostarczanych przez organizację }\end{array}$ & $\begin{array}{l}\text { Obcowanie z klientem dostarcza wiele stresu } \\
\text { i frustracji, co może być spowodowane rów- } \\
\text { nież zaangażowaniem emocjonalnym w sprawy } \\
\text { klienta }\end{array}$ \\
\hline \multicolumn{2}{|c|}{ Menedżer } \\
\hline $\begin{array}{l}\text { Ma możliwość kierowania administracyjnego } \\
\text { oraz skupia większą uwagę na procesach eko- } \\
\text { nomicznych i rynkowych, a co za tym idzie na } \\
\text { efektywności i wydajności pracy }\end{array}$ & $\begin{array}{l}\text { Coraz częściej musi kierować na wpół autono- } \\
\text { micznymi grupami zadaniowymi realizującymi } \\
\text { poszczególne programy. Zmniejszenie środków } \\
\text { materialnych wymaga umiejętności w osiąganiu } \\
\text { obniżania kosztów usług socjalnych bez obniża- } \\
\text { nia jakości oraz konieczność ciągłego dostoso- } \\
\text { wywania się do zmiennych potrzeb tworzenia } \\
\text { nowych programów, systemów opieki itd. }\end{array}$ \\
\hline
\end{tabular}

Opracowano na podstawie: J. Krzyszkow ski: Elementy organizacji i zarzadzania w pomocy społecznej. Ośrodek Kształcenia Służb Publicznych i Socjalnych — Centrum AV, s. 29-31.

Różnica jest bez wątpienia znaczna, co można streścić w następującym przykładzie: pracownik sklepu, warsztatu ma satysfakcję z faktu, że klient do 
niego wraca - jest to niejako wyznacznik tego, jak dobrze wykonuje swoją pracę i tą ścieżką buduje zaufanie, tym samym pomnażając zysk i inne, niematerialne korzyści z tego tytułu (prestiż, uznanie, szacunek). Zupełnie odwrotnie działa pracownik socjalny. Dlaczego? Jako osoby pomagające i stymulujące dążenie do samodzielności odnosimy sukces, gdy podopieczny nie wraca i jest w stanie sam zmagać się z trudnościami życiowymi. Nie zawsze jest to możliwe nie tylko z uwagi na trudności w całym procesie, lecz także ze względu na charakter placówek, w których przychodzi funkcjonować. Jeśli weźmiemy pod uwagę dom pomocy społecznej, to prace pomocowe — przynajmniej w ujęciu modelowym — trwają tam nieustannie, na różnych płaszczyznach i trudno, aby tamtejsi klienci nie wracali, chociażby dlatego, że są stałymi mieszkańcami. Dom Pomocy Społecznej w mieście X [dalej: DPS] jest tym, w którym zrealizowaliśmy badania, dlatego w niewielkim skrócie przytoczymy teraz jego cele, zakres działania oraz zasady funkcjonowania (Uchwała nr 777/LVII/10 Rady Miejskiej Miasta X z dnia 25 marca 2010 r.).

\section{Cele, zakres działania DPS, zasady funkcjonowania}

1. Dom przeznaczony jest dla 80 osób w wieku podeszłym i ma charakter domu stacjonarnego.

2. Celem DPS jest świadczenie usług bytowych, opiekuńczych oraz wspomagających i edukacyjnych na poziomie obowiązującego standardu, w zakresie i formach wynikających $\mathrm{z}$ indywidualnych potrzeb mieszkańców oraz umożliwienie korzystania ze świadczeń przysługujących z tytułu powszechnego ubezpieczenia społecznego.

3. DPS świadczy podstawowe usługi zgodnie z obowiązującym standardem określonym przepisami prawa.

4. DPS świadczy usługi uwzględniając stan zdrowia, sprawność fizyczną i intelektualną, a także indywidualne potrzeby i możliwości mieszkańców. Zapewnia również prawo do godności, wolności, intymności i poczucia bezpieczeństwa.

5. W celu realizacji działań statutowych DPS współpracuje z działającymi na terenie Miasta jednostkami budżetowymi, jednostkami organizacyjnymi pomocy społecznej, organizacjami społecznymi, Kościołem Katolickim i innymi kościołami, związkami wyznaniowymi, fundacjami, stowarzyszeniami, organizacjami pożytku publicznego oraz innymi podmiotami.

6. Do DPS kierowane są osoby na podstawie decyzji administracyjnej.

7. Decyzję o skierowaniu do DPS i decyzję ustalającą opłatę za pobyt wydaje organ gminy właściwy dla tej osoby w dniu kierowania do domu pomocy społecznej.

8. Pobyt w DPS jest odpłatny. Wysokość opłat oraz sposób ich pobierania regulują przepisy ustawy o pomocy społecznej oraz przepisy wykonawcze do ustawy. 


\section{Mobbing w teorii}

Środowisko pracy jest miejscem, gdzie każdy z nas spędza sporą część swojego życia, chcąc jak najlepiej wypełniać obowiązki zawodowe. Nie zawsze traktujemy pracę czysto instrumentalnie, wyłącznie jako sposób zarabiania pieniędzy, lecz znajdziemy takie jednostki, które swoim działaniem pokazują, że wykonywany zawód jest dla nich czymś więcej, czymś ważniejszym, bardziej doniosłym powołaniem. Jeśli chcielibyśmy stworzyć najprostszy pożądany katalog cech osobowościowych pracownika placówki pomocowej, to nasunęłyby się nam następujące skojarzenia:

- empatyczny,

— bezinteresowny,

— oddany swojej pracy,

— umiejący współpracować z ludźmi,

- umiejący słuchać,

— otwarty na kontakty z ludźmi,

- odpowiedzialny,

— wytrwały w dążeniu do celu.

Wykaz cech nie jest bez wątpienia zamknięty, ale właśnie te pozytywne cechy zestawilibyśmy, gdybyśmy mieli stworzyć pożądaną sylwetkę pracownika socjalnego czy terapeuty zajęciowego. Oczywiście, mówimy tutaj najczęściej o typie idealnym (Weber, 2004, s. 324), będącym wyznacznikiem cech pożądanych z punktu widzenia tych konkretnych zawodów.

Zanim uszczegółowimy przedmiot analizy i przejdziemy do omówienia, czym jest mobbing, pójdźmy za Ryszardem Stockim i zdefiniujmy patologię organizacji. Prezentuje ją jako każdą dysfunkcję w organizacji niepozwalającą na osiągnięcie realistycznych, wyznaczonych danej organizacji i zgodnych z dobrem społecznym celów w zakładanym czasie i w określonych warunkach (Stocki, 2005, s. 50). Innym przykładem jest definicja Jacka Pasiecznego, który definiuje patologię zarządzania opisując ją jako długotrwałą istotną nieprawidłowość w procesach zarządzania organizacją lub wyodrębnioną część nauki o zarządzaniu, zajmującą się analizą funkcjonowania nieprawidłowości w zarządzaniu. Reasumuje, że dysfunkcja organizacji prowadzi do zakłóceń sprawnego funkcjonowania organizacji, a dysfunkcja zarządzania uniemożliwia lub utrudnia właściwe zarządzanie wybranym systemem organizacyjnym (Pasieczny, 2012, s. 118).

Nierzadko jest tak, że miejsce, w którym człowiek pracuje, jest miejscem bezkonfliktowym, o małym nasileniu stresu, ale może być też miejscem powodującym rozmaite patologie, jak: mobbing, molestowanie, agresja, manipulacja (Kozak, 2009, s. 136-186). Podejmując temat, warto zdać sobie sprawę z jednej istotnej kwestii, wydawałoby się oczywistej. Chodzi mianowicie o ogromny trud wykrycia zachowań mobbingowych. Jeśli zdefiniujemy za Jarosławem Marciniakiem, że „to proces nękania pracownika trwający nie mniej niż 6 miesięcy, stosowany systematycznie przynajmniej raz w tygodniu, godzący w godność, osobowość lub integral- 
ność psychiczną czy fizyczną człowieka, stanowiący zagrożenie dla jego zatrudnienia oraz wpływający na pogorszenie atmosfery i wydajności pracy" (Marciniak, 2011, s. 11), to od razu jawią nam się przede wszystkim koszty psychiczne, jakie ponosi ofiara takich działań. Cały dramat dotyczy nie tylko samego procederu jako takiego, lecz zmowy milczenia panującej najczęściej w takich sytuacjach, co prowadzi do osamotnienia w kontekście tego problemu. Warto wspomnieć postać Heinza Leymanna, który obserwując zachowania tzw. ludzi trudnych w środowisku wykonywania przez nich pracy zapoczątkował badanie mobbingu w Szwecji, a następnie w Niemczech i w 1984 roku opublikował raport, w którym zawarł konkluzję, że mobbing należy odczytywać jako psychologiczny terror, na który składają się: systematycznie wrogi i nieetyczny sposób porozumiewania się członka grupy lub całego zespołu pracowniczego z jednym z jej członków, który został przezeń zepchnięty do pozycji obronnej i pozbawiony pomocy (Ley mann, 1996, s. 45). Zgodnie z art. 943 §. Kodeksu pracy mobbing oznacza „działania lub zachowania dotyczące pracownika lub skierowane przeciwko pracownikowi, polegające na uporczywym i długotrwałym nękaniu lub zastraszaniu pracownika, wywołujące u niego zaniżoną ocenę przydatności zawodowej, powodujące lub mające na celu poniżenie lub ośmieszenie pracownika, izolowanie go lub wyeliminowanie z zespołu współpracowników".

$\mathrm{Z}$ całą pewnością można zestawić to pojęcie z pojęciem przemocy, które Irena Pospiszyl definiuje jako „wszelkie nieprzypadkowe akty godzące w osobistą wolność jednostki lub przyczyniające się do fizycznej, a także psychicznej szkody osoby, które wykraczają poza społeczne normy wzajemnych kontaktów międzyludzkich" (Pos piszyl, 1998, s. 16). Ponadto zaznaczyć należy jeszcze jedną rzecz: nie powinniśmy stawiać znaku równości między mobbingiem a konfliktami interpersonalnymi, które są czymś naturalnym w każdym elemencie życia społecznego. Konflikt - w przeciwieństwie do nękania - może przynieść pozytywne skutki $\mathrm{w}$ postaci wypracowania konsensusu, zorganizowania się w konkretnym celu i przedsięwzięcia działań korzystnych z punku widzenia organizacji.

Gdy już zdefiniowano kluczowe pojęcie, warto zastanowić się nad tym, co może być przyczyną omawianego postępowania (tab. 2).

Tabela 2

Przyczyny mobbingu

\begin{tabular}{|l|l|}
\hline \multicolumn{1}{|c|}{ Przyczyna } & \multicolumn{1}{c|}{ Wyjaśnienie } \\
\hline Czynniki indywidualne & $\begin{array}{l}\text { Cechy osobowości, odmienność zachowań, płeć, wiek, wykształ- } \\
\text { cenie, stan cywilny, pozycja zawodowa }\end{array}$ \\
\hline Czynniki organizacyjne & $\begin{array}{l}\text { Nieodpowiednie kierownictwo, złe zarządzanie, niewłaściwa or- } \\
\text { ganizacja pracy, kultura organizacji, nieprzyjazny klimat, stresu- } \\
\text { jące środowisko pracy }\end{array}$ \\
\hline Czynniki społeczne & $\begin{array}{l}\text { Poziom przestępczości, zmiany ekonomiczne, szybko postępują- } \\
\text { ce zmiany społeczne }\end{array}$ \\
\hline
\end{tabular}

Źródło: Kozak, 2009, s. 177 
Nie sposób przeoczyć szerokiej gamy czynników determinujących to dysfunkcyjne zachowanie. Kierunek takich działań najczęściej ma charakter pionowy i biegnie z góry na dół, a więc od osoby postawionej wyżej w drabinie przedsiębiorstwa wobec tej, która jest niżej. Mobber wykorzystuje swoją pozycję społeczną, kojarzoną z sukcesem, co dodatkowo ma podkreślić jego siłę, tymczasem paradoksalnie jest jednostką słabą, obawiającą się o swoje miejsce, uciekającą się do agresywnych form deprecjonowania innych, umniejszania wartości drugiego człowieka. Sprzyja temu dominująca na rynku pracy niepewność zatrudnienia (Chirkowska-Smolak, Grobelny, red., 2015, s. 23), która prowadzi do nieustannej obawy i sprzyja pojawianiu się różnych form patologii, w tym mobbingu.

W jaki sposób działa sprawca? Niejednokrotnie niezauważalnie, lecz nawet gdy inni pracownicy mają świadomość takich poczynań, przeważnie pozostają na nie obojętni. Przyczyn takich reakcji może być wiele, począwszy od obawy o własne stanowisko pracy aż po zwyczajną złośliwość i satysfakcję z wyeliminowania kogoś innego.

Piotr Chomczyński (2008, s. 92-93) zwraca uwagę na trzyetapowy model Einarsena i Bjorkvista, oparty na obserwowanej zmianie intensywności wzajemnych oddziaływań. Wyróżnia:

a) działania pośrednie, typu rozsiewanie plotek, przeszkadzanie w pracy (poniżanie ofiary w oczach innych ludzi);

b) bardziej bezpośrednie techniki oparte na izolacji oraz publicznym krytykowaniu i ośmieszaniu (publiczne usprawiedliwianie własnych zachowań przez dyskredytację ofiary i wyzbycie się ewentualnych wyrzutów sumienia);

c) działania skoncentrowane na wytworzeniu publicznego wizerunku ofiary jako osoby chorej umysłowo, nieracjonalnej; osoba na tym etapie często bywa szantażowana (uniemożliwienie ofierze dochodzenia swoich praw, przeciągnięcie środowiska ofiary na swoją stronę).

Przedstawiona typologia nasuwa na myśl teorię dramaturgiczną Goffmana, w której konkretni aktorzy starają się jak najlepiej odegrać swoje role, by wywrzeć jak największy wpływ na widownię. Tą drogą emitują pozytywne sygnały na swój temat, grają przed drugimi, starając się przedstawić samych siebie w dobrym świetle, a czynią to w celu osiągnięcia wymiernych korzyści (Sztompka, 2010, s. 80-81). Mobber umniejszając wartość ofiary przed swoim ,audytorium” buduje w ten sposób swoją opinię, ukrywając własne słabości, wady, kompleksy, które są przyczynkiem takiego działania.

Inaczej cechy mobbingu za Leymannem, który charakteryzuje je w rozbudowanej formie, ujmuje Jolanta Kowal (2011, s. 232) przedstawiając je w tabeli (tab. 3).

Jak już wspomniano, te elementy, które określiliśmy jako sposób lobbowania, muszą występować przez co najmniej pół roku z częstotliwością przynajmniej raz w tygodniu. Z badań CBOS przeprowadzonych w 2014 roku wynika, że mniej więcej co szósty pracownik (17\%) deklaruje, że w ciągu ostatnich 5 lat był szykanowany przez swojego przełożonego, w tym co dwudziesty (5\%) twierdzi, że działo się to często. Blisko co czwarty zatrudniony (24\%) deklaruje, że w jego miejscu pracy zdarzały się przypadki szykanowania przez przełożonych, a prawie co piąty (17\%) 
mówi o szykanach ze strony koleżanek, kolegów (CBOS, 2014, Szykany w miejscu pracy). Warto pamiętać, że dotykamy tematyki, którą zwykło się określać jako delikatną, a przecież nie jest łatwo mówić o tego typu doświadczeniach i część z nich może mieć charakter ukryty, niewykrywalny.

Tabela 3

Sposoby mobbowania

\begin{tabular}{|l|l|}
\hline \multicolumn{1}{|c|}{ Sposób mobbowania } & \multicolumn{1}{|c|}{ Charakterystyka } \\
\hline $\begin{array}{l}\text { Oddziaływanie zaburzające możliwości komu- } \\
\text { nikowania się }\end{array}$ & $\begin{array}{l}\text { Ograniczenie możliwości wypowiadania się, } \\
\text { przerywanie wypowiedzi, ciąge krytykowa- } \\
\text { nie, groźby i pogróżki, upokarzanie przez gesty, } \\
\text { spojrzenia, czynienie aluzji, bez jasnego wyra- } \\
\text { żania wprost }\end{array}$ \\
\hline Oddziaływanie zaburzające stosunki społeczne & $\begin{array}{l}\text { Unikanie rozmów z ofiarą, niedawanie moż- } \\
\text { liwości odezwania się, zabronienie rozmów } \\
\text { zofiarą, traktowanie ofiary ,jak powietrze” }\end{array}$ \\
\hline $\begin{array}{l}\text { Działania mające na celu zaburzenie społeczne- } \\
\text { go odbioru osoby }\end{array}$ & $\begin{array}{l}\text { Mówienie źle za plecami danej osoby, rozsie- } \\
\text { wanie plotek, próby ośmieszania, sugerowanie } \\
\text { choroby psychicznej, wyśmiewanie niepełno- } \\
\text { sprawności, parodiowanie sposobu chodzenia, } \\
\text { mówienia, gestykulacji, uderzanie w przekona- } \\
\text { nia ofiary, żarty z życia prywatnego, fałszywe } \\
\text { ocenianie zaangażowania w pracy, kwestio- } \\
\text { nowanie podejmowanych decyzji, stosowanie } \\
\text { przezwisk }\end{array}$ \\
\hline $\begin{array}{l}\text { Działania mające wpływ na jakość sytuacji ży- } \\
\text { ciowej i zawodowej }\end{array}$ & $\begin{array}{l}\text { Brak zadań do wykonania, odbieranie prac, zle- } \\
\text { canie wykonania prac bezsensownych, zarzuca- } \\
\text { nie ciągłymi pracami do wykonania, polecenie } \\
\text { wykonywania zadań obraźliwych, dawanie za- } \\
\text { dań przerastających możliwości i kompetencje }\end{array}$ \\
\hline $\begin{array}{l}\text { Działania mające szkodliwy wpływ na zdrowie } \\
\text { ofiary }\end{array}$ & $\begin{array}{l}\text { Zmuszanie do wykonywania prac szkodliwych } \\
\text { dla zdrowia, grożenie przemocą fizyczną, znę- } \\
\text { canie się, wyrządzanie szkód psychicznych, } \\
\text { działania o podłożu seksualnym }\end{array}$ \\
\hline
\end{tabular}

Źródło: J. Kowal: Mobbing jako problem etyki w zarządzaniu. http://www.annalesonline.uni.lodz.pl/archiwum/2011/2011_ 01_kowal_pilarek_227_240.pdf [dostęp: 22.03.2018].

Joanna Wyleżałek proponuje spojrzeć na mobbing z perspektywy gry, w której zachowania organizacyjne aktora powinny być traktowane jako wyraz racjonalnej strategii zmierzającej do maksymalnego wykorzystania swej władzy w celu zwiększenia wygranych organizacyjnych, zaś strategie działania przyjmowane przez aktorów organizacyjnych zawierają dwa przeciwstawne i komplementarne aspekty, czyli unikanie ograniczeń swobody własnej (strategia defensywna) i dążenie do ograniczenia swobody działań innych uczestników (strategia ofensywna) (Wyleżałek, 2012, s. 96). Konfiguracja tych stosunków oraz przyjmowane przez aktora strategie działania tworzą rzeczywistą osnowę życia organizacyjnego, 190 łącząc rozbieżne $\mathrm{z}$ natury cele poszczególnych aktorów i nadając im wymiar 
społeczny — funkcjonowanie jest zatem rezultatem zderzenia się specyficznych racjonalności zróżnicowanych i stosunkowo autonomicznych aktorów wykorzystujących w działaniu dostępną im władzę. Patologiczne jej okazywanie jest jedną z grup mobbingowych zachowań. Na czym takie zachowanie powinno się opierać? Bez wątpienia na wiedzy, profesjonalizmie, zaufaniu, szacunku itd., bo przecież to buduje autorytet. W omawianej patologii jest to demonstrowane siłowo, w sposób nieuzasadniony, przez agresję słowną, a skutki są odczuwalne nawet po długim czasie. Odwołując się do wspomnianej perspektywy gry, mobbing jest rodzajem gry, w której strategie przyjmowane przez aktorów-mobberów są rozbieżne z celami organizacji, co zagraża zarówno realizacji własnych celów przez poszczególne jednostki, jak i istnieniu organizacji jako całości. Manipulacyjny charakter tej gry czyni jednak przyjęte przez mobbera strategie nieczytelnymi dla większości aktorów, również dla tych, którzy w grze uczestniczą. Aktorzy włączeni w grę i przekonani o zasadności swoich działań podejmują strategie, które nie tylko zmierzają do eliminacji jednostek lub zbiorowości zagrażających marginesowi swobody mobbera, ale w rezultacie ograniczają ich własną swobodę (Wyleżałek, 2012, s. 96-103).

Mobbing jest przeżyciem traumatycznym, mającym ogromny wpływ na zdrowie osoby, powodującym urazy psychosomatyczne. Prześladowany pracownik jest stale zestresowany, nie skupia się na pracy, popełnia błędy, a jego wydajność się obniża. Często wykorzystuje zwolnienia lekarskie, bo to pozwala uciec od prześladowcy. Spośród występujących zaburzeń można wymienić: bezsenność, bóle głowy, nadciśnienie tętnicze, problemy kardiologiczne itp. Pogłębiają się stany lękowe i pojawiają się myśli samobójcze. Skutki działań przenoszone są również na życie prywatne, w wyniku czego cierpią często całe rodziny (Kurowska, 2016, s. 60). Również organizacja ponosi koszty takiego działania - zmniejszenie efektywności, zaangażowania pracowników, pogorszenie wizerunku firmy to tylko kilka przykładów negatywnego oddziaływania. Można rzec, że na zaufanie pracuje się latami, a można je zniszczyć bardzo szybko. Czy można przeciwdziałać lub minimalizować to zjawisko? Za Agatą Bechowską-Gebhardt i Tadeuszem Stalewskim można przytoczyć kilka form przeciwdziałania mobbingowi (Bechowska-Gebhardt, Stalewski, 2004, s. 63-64):

1. Występuje jasny i wyraźnie określony podział kompetencji i zadań.

2. Występują precyzyjnie określone systemy ocen pracowników.

3. Systemy i zasady wynagradzania są jasne i sprawiedliwe.

4. System awansowania jest jasno określony.

5. Opracowuje się dla pracowników ścieżki karier.

6. Ma miejsce swobodny przepływ informacji.

7. Wszyscy pracownicy znają sposoby i zasady podejmowania decyzji.

8. Kierownictwo bierze pod uwagę opinie, zdania i pomysły podwładnych.

9. Kierownictwo chętnie deleguje pewną część swych uprawnień decyzyjnych na podwładnych.

10. Poza motywacją płacową stosuje się również motywację pozapłacową.

11. Występuje dbałość o zadowolenie i satysfakcję z pracy. 
12. Występują pozytywne struktury nieformalne, takie jak: zespoły zadaniowe i grupy koleżeńskie.

13. Kierownictwo cechuje dbałość o poznanie się i integrację pracowników.

14. Nie występuje system represji i nadmiernej kontroli podwładnych.

15. Kierownictwo stara się stworzyć swym podwładnym warunki do efektywnej i twórczej pracy.

16. Przełożony propaguje prawidłowe wzorce zachowań u podwładnych.

17. Kierownictwo szanuje godność człowieka.

18. Osoby na stanowiskach kierowniczych cechuje duża kultura osobista, życzliwość i otwartość.

19. Stosuje się właściwe dla specyfiki organizacji procedury rekrutacji i selekcji personelu.

20. Inwestuje się w rozwój zawodowy pracowników.

21. Kierownictwo potrafi rozpoznać zdolności pracownika i właściwie to wykorzystać dla firmy.

22. Przełożeni posiadają umiejętności właściwego wyrażania krytyki oraz pochwał. $\mathrm{Na}$ podstawie tych informacji stwierdzamy, że zjawisko mobbingu nie jest w pełni uchwytne. Przytoczenie form przeciwdziałania było nieodzowne w kontekście studium przypadku placówki, która została poddana obserwacji i w której modelowo można było zaobserwować działania zasygnalizowane w części teoretycznej. Truizmem jest stwierdzenie nieodzowności badania tego obszaru wiedzy oraz uświadamiania pracowników (i nie tylko) o istotności tego problemu i jego konsekwencjach. Nie dotyczy on przecież tylko środowiska pracy, może dotyczyć także szkoły, czy chociażby relacji wewnątrzrodzinnych. Cena jest ogromna, bo przecież mamy do czynienia z ludźmi, ich odczuciami, emocjami, funkcjonowaniem i zestawem praw, które w taki sposób są naruszane, deptane. Mechanizm działań mobbera nie jest prosty do zidentyfikowania, co niech potwierdzi fakt, że dopiero po roku udało nam się uzyskać informacje na temat procederu mającego miejsce w placówce pomocowej.

\section{Mobbing w praktyce, czyli studium przypadku DPS Przypadek nękania i jego uwarunkowania}

Obserwacja uczestnicząca ukryta polega na tym, że prowadzący badanie pozostaje całkowicie ukryty, a osoby badane nie znają celu badań, obserwator zaś staje się członkiem danej grupy. Wchodzi w interakcje z badanymi w sposób tak naturalny, jak to tylko możliwe, i w tych sytuacjach życiowych, które są dla niego interesujące i dostępne (Frankfort-Nachmias, Nachmias, 2001).

Zastosowanie obserwacji uczestniczącej ukrytej wydawało się najlepszym rozwiązaniem umożliwiającym zaobserwowanie tego zjawiska $\mathrm{w}$ praktyce.

192 Z uwagi na charakter opisywanego zjawiska, zarówno z perspektywy organizacji, 
jak i z perspektywy jednostkowej, metoda ta okazała się najbardziej pomocna. Dodajmy, że nie byłoby możliwości realizacji badania, gdyby nie fakt, że przez dwa lata byliśmy wolontariuszami $\mathrm{w}$ tym miejscu, co poskutkowało zaufaniem osoby mobbowanej. Tyle też trwała obserwacja oraz wywiady mające grunt nieformalny, niestrukturalizowany. Paradygmat, który zastosowaliśmy w analizie, dotyczy gry organizacyjnej i z tej też perspektywy analizujemy zjawisko, zaś obiekt badań znajduje się w jednym z miast w województwie śląskim. Podążając za Davidem Silvermanem wyróżnijmy następujące kategorie odbiorców i zespół ich oczekiwań (Silverman, 2007, s. 289):

- koledzy akademiccy, których oczekiwania skupiają się wokół wnikliwości teoretycznej, faktograficznej lub metodologicznej;

— decydenci polityczni — informacje praktyczne, istotne dla aktualnej linii politycznej;

- praktycy - ramy teoretyczne do lepszego zrozumienia klientów, dane oparte na faktach, praktyczne wskazówki prowadzące do ulepszenia stosowanych praktyk;

— ogół odbiorców - nowe fakty, pomysły na zreformowanie stosowanych praktyk bądź polityk; wskazówki, jak lepiej wykorzystać i jak skutecznie radzić sobie z praktykami oraz instytucjami; potwierdzenie, że inni podzielają ich doświadczenia związane z określonymi aspektami życia.

$\mathrm{Na}$ tej podstawie możemy stwierdzić, że główną linią odbiorców powinni być koledzy akademiccy, praktycy oraz ogół odbiorców, choć szczególny nacisk położylibyśmy na dwie końcowe kategorie, ponieważ obserwacja dotyczyła instytucji działającej na rzecz społeczeństwa, co oznacza, że dla nich uwagi w trakcie analizy - z naszego punktu widzenia - mogą okazać się cenne. Zanim jednak przejdziemy do omawiania wyników obserwacji, przyjmiemy konkretne nazwy dla poszczególnych osób:

- osoba mobbowana: Pani Kowalska,

- mobber: Pani Nowak.

Pozwoli to na usystematyzowanie i niepogubienie się w toku analizy, a także ułatwi odbiór czytelnikowi. Aby opracowanie było przejrzyste, odpowiednio wyczerpujące, musimy powrócić do początku działalności w DPS, a więc do momentu, kiedy mieliśmy za zadanie odbyć praktyki w tej placówce $\mathrm{w}$ ramach studiów na kierunku ,praca socjalna”. Posłużymy się tu pojęciem „stereotyp”, które w szerszym ujęciu zastosował Elliot Aaronson, opisując stereotyp jako generalizację odnoszącą się do grupy, w ramach której identyczne charakterystyki zostają przypisane wszystkim bez wyjątku jej członkom, niezależnie od rzeczywistych różnic między nimi (A aron son, Wilson, Alert, 1997, s. 543). Bogdan Wojciszke pisze zaś, że to tradycyjnie rozumiany, nadmiernie uogólniony i uproszczony obraz określonej grupy społecznej, zwykle podzielany przez większą zbiorowość ludzi (Wojciszke, 1991, s. 180). Stereotypy na temat domów pomocy społecznej są różne i rzecz jasna nas nie ominęły $\mathrm{i}$ - podobnie jak wiele osób - mieliśmy taki uproszczony obraz rzeczywistości, w której przyszło nam funkcjonować. Nie miały one charakteru pozytywnego. 
Nie będziemy mówić naturalnie o wszystkich elementach naszych praktyk, skupiliśmy się raczej na konkretnych sytuacjach, w których mobbing się przejawiał i w których z całym przekonaniem możemy wnioskować, że mamy z nim do czynienia, ponieważ czas i poszczególne zdarzenia nie pozostawiały w tym zakresie żadnych wątpliwości. Pierwsze sygnały, nieodczytane wówczas przez nas jako przejawy omawianej patologii, miały miejsce podczas początkowych dwóch miesięcy naszej działalności w DPS. Była to pora letnia, więc doskonała okazja, aby z seniorami pojechać do parku, by zaczerpnęli świeżego powietrza i chociaż na chwilę zmienili otoczenie w celu lepszego samopoczucia. Pani Kowalska, jako terapeuta zajęciowy zatrudniony na 3/4 etatu, była osobą uczestniczącą w tych wyjazdach, a my jej towarzyszyliśmy jako studenci, przyszli wolontariusze placówki. Sytuacje zdawały się niewinne, gdy kilkukrotnie Pani Kowalska szukała aparatu, aby zrobić zdjęcia w celu udokumentowania, co działo się w poszczególnych dniach w DPS i czym seniorzy się zajmowali. Widać było jej niepokój w poczynaniach, nerwowość w szukaniu, ale wówczas nie mogliśmy zdawać sobie sprawy, w czym tkwi problem. Jak się okazało, aparat fotograficzny był celowo chowany przez stażystkę, czyli osobę będącą blisko z Panią Nowak. Działo się to niemal zawsze, gdy Pani Kowalskiej nie było w pracy i tym samym nie miała dostępu do biblioteki i przylegającego do niej pomieszczenia, w którym odbywały się zajęcia terapeutyczne. W rozmowie z nami Pani Kowalska kilkukrotnie twierdziła, że stażystka powiedziała wprost, że chodzi jej o to, aby uczynić z terapeutki osobę nieracjonalną, zaburzoną psychicznie, niezdolną wykonywać należycie swych funkcji. Czy to było początkowe stadium rozwoju mobbingu? Nie jesteśmy w stanie odpowiedzieć na to pytanie. Możemy jedynie przypuszczać na podstawie zdobytej wiedzy, że nie były to pierwsze tego typu sytuacje i wydaje się, że nie ma podstaw, aby nie ufać tym stwierdzeniom.

Jak się okazało, były to początki i dopiero zalążki późniejszych działań Pani Nowak. Warto zaznaczyć, że kultura organizacyjna i cechy otoczenia (Durniat, 2012, s. 213 - 222) nie sprzyjały temu, aby działania mobbingowe były jakkolwiek piętnowane. Augustyn Bańka pisze o warunkach sprzyjających tej formie przemocy, do których zalicza (Bańka, 2000, s. 323):

- autokratyczny styl zarządzania,

- sztywne struktury hierarchii,

- traktowanie pracownika służbowo,

- chaos w zarządzaniu,

- walka o awans,

- strach o pracę.

Wymienione warunki wskazują na środowisko korporacyjne, w którym jednostki walczą o awans, chcą się piąć po drabinie struktury społecznej i niejednokrotnie posuwają się do różnych zachowań, aby tę satysfakcjonującą pozycję zdobyć. W omawianym studium przypadku przejawia się głównie chaos w zarządzaniu. O stylu autokratycznym nie może być mowy ze strony dyrekcji, natomiast kierownik, którym jest Pani Nowak, ,lubi, jak jest po jej myśli i potrafi

194 tego dopiąć”. 
Ktoś może zadać pytanie: Jaka była reakcja osoby czuwającej nad całą placówką, czyli Pani Dyrektor? Niestety, otoczenie określało ją jako „miękką”, „dającą się łatwo manipulować” i ,uległą”, wobec czego osoba budująca swoją przewagę psychiczną na agresji miała rozszerzone pole działania. Zauważali to mieszkańcy DPS, twierdząc, że „czują się jak na poniewierce”, „kompletnie nieprzydatni”, „traktowani gorzej niż ścierka do wycierania kurzu”. Co w tym uderza najbardziej? Fakt, że sprawa dotknęła osób starszych w sposób bezpośredni, o czym również należy powiedzieć. Dlaczego? Pani Kowalska już nie pracuje w DPS, a jej obowiązki przejęła Pani Nowak. Kilkoro mieszkańców niejednokrotnie poruszało temat zajść między ofiarą a oprawcą i nawet $\mathrm{w}$ dwa miesiące po odejściu Pani Kowalskiej pensjonariusze czują się opuszczeni i zostawieni na pastwę losu, bo osoba odpowiedzialna za zajęcia terapeutyczne, czyli Pani Nowak, nie wykonuje swoich obowiązków.

Sama procedura odejścia Pani Kowalskiej z pracy miała klasyczne elementy znane z takich patologicznych poczynań. Można było zaobserwować sinusoidę, w której dominowały rezygnacja z jednej strony, a z drugiej chęć walki i utrzymania się w pracy. Punktem zwrotnym był prawie dwutygodniowy urlop, na który ofiara zdecydowała się ze względów zdrowotnych. $Z$ rozmów, które prowadziliśmy z nią podczas jej nieobecności w pracy, wynikało, że mąż nalegał, aby zrezygnowała z pracy i z walki, którą zaczyna przypłacać zdrowiem. Na czas nieobecności dozór nad miejscem pracy Pani Kowalskiej przejęła Pani Nowak i przez te dwa tygodnie mieszkańcy skarżyli się na brak zajęć terapeutycznych. To był czas, kiedy już nie byliśmy praktykantami, lecz wolontariuszami i po zjawieniu się na miejscu pracy widzieliśmy ogromny bałagan. Jak się później okazało, nie był to bałagan wynikający z trudów pracy, lecz z chęci udowodnienia, że Pani Kowalska nie nadaje się do pełnienia funkcji terapeuty, ponieważ jest zbyt chaotyczna i nie dba o swoje stanowisko. Przyszedł w końcu czas, kiedy pracownikom należało przedłużyć umowę - wedle wszelkich relacji był to przełom października i listopada, jednak pracownicy zawsze otrzymywali nieco wcześniej informację o tym, czy umowa zostanie im przedłużona. Kiedy wszyscy już byli świadomi decyzji dyrekcji, jedynie Pani Kowalska pozostawała do ostatniego dnia umowy w niepewności, a temat był ignorowany. Finalnie umowa została przedłużona, jednak Pani Kowalska niedługo potem udała się na urlop, z którego już nie wróciła, gdyż mąż dostarczył wypowiedzenie umowy. Stan zdrowia Pani Kowalskiej na tyle się pogorszył, że potrzebna była rekonwalescencja. Lekarz jednoznacznie stwierdził, że schorzenia są skutkiem długotrwałego stresu i nerwów.

Zawsze, gdy w grę wchodzi nieszczęście jednego człowieka spowodowane przez drugą jednostkę, nasuwa się pytanie, dlaczego dochodzi do takich sytuacji? Odcinając się na chwilę od chaosu w organizacji, postanawiamy skupić się na kwestii społeczno-demograficznej dwóch kobiet. Z teorii jasno wynika, że mobberami są najczęściej osoby o wyolbrzymionym poczuciu własnej wartości, nieufne, niebiorące pod uwagę krytyki innych ludzi, przejaskrawiające własne możliwości. Osoby takie nie odczuwają wyrzutów sumienia, a poniżanie innych jest receptą na dowartościowanie siebie samych (Budgol, 2007, s. 81—82). Co z tego wynika? 
Przede wszystkim to, że mobberzy to jednostki niepogodzone ze sobą, mające kompleks niższości i słabsze — przynajmniej pod względem kompetencji, umiejętności - od ofiary. W zestawieniu omawianych postaci obserwujemy również te dysproporcje między nimi, ponieważ Pani Kowalska jest absolwentką studiów pedagogicznych, a Pani Nowak zakończyła edukację na liceum plastycznym, więc poczucie zagrożenia w związku z zajmowanym stanowiskiem kierownika jest uzasadnione. Co więcej, Pani Kowalska nadal się dokształcała i z tego powodu w środy była nieobecna w miejscu pracy. Byliśmy świadkami, kiedy Pani Nowak puściła w obieg plotkę, że Pani Kowalska „tak naprawdę nie uczęszcza do żadnej szkoły, tylko nie chce się jej pracować”, a znajoma Pani Nowak ,akurat jest sekretarką w tejże szkole i potwierdza, że takiej osoby jak Pani Kowalska nie ma nigdy na zajęciach w środy". Była to przekazana niemal wszystkim pracownikom DPS wiadomość, z której jasno wynikało, że ofiara kłamie i unika pracy. Gdy informacja dotarła do Pani Kowalskiej, ta od razu udała się do dyrekcji w celu wyjaśnienia sprawy, dostarczając poświadczenie z sekretariatu szkoły, że zainteresowana uczęszcza na zajęcia i systematycznie wpisuje się na listę obecności. Reakcja dyrekcji DPS nie była zdecydowana i Pani Nowak nie poniosła żadnych konsekwencji za te insynuacje.

Milczenie bardzo często jest przyzwoleniem. Należy dodać, że przykre sytuacje w omawianym DPS dotykały także mieszkańców, choć niekoniecznie były związane z mobbingiem. W pewnym momencie zatrudniono wolontariuszkę, która mając wykształcenie fizjoterapeutyczne mogła pomagać seniorom w funkcjonowaniu, szczególnie w takich przypadkach, kiedy mieli problemy ruchowe, koordynacyjne. Do zadań fizjoterapeutki należała praca nad sposobem poruszania się jednego z mężczyzn, który chodził z pomocą balkonika, poza tym nie wykazywał żadnych deficytów umysłowych, słuchowych itd. Gdy zaczynaliśmy praktyki w wakacje 2016 roku, stałym punktem codziennych zajęć było wyprowadzanie pensjonariuszy do ogrodu. Podczas naszej wizyty jedna z salowych zwróciła się do podopiecznego następującymi słowami: „Panie S., śmierdzisz pan jak cap i jeszcze ten popiół na ubraniach". Wracamy do tej sytuacji z tego względu, że wspomniana wolontariuszka pewnego dnia zachęciła mężczyznę, aby wyszedł na spacer po korytarzu i chcąc zachęcić go do większego wysiłku, przyszła z nim na pierwsze piętro. Zdobyła jego zaufanie $\mathrm{i}$ - jak sama zaznacza - widziała postępy w sposobie poruszania się, co miało odzwierciedlenie w samopoczuciu pacjenta. W trakcie ćwiczenia zjawiła się Pani Dyrektor i zaleciła, aby „wziąć pana gdzieś na dół, na parter, bo za chwilę mają przyjść ludzie i dobrze by było, aby się z nim nie pokazywać tak otwarcie, na holu". Nie trzeba dodawać, że podopieczny słyszał te słowa. Zaraz potem wyjaśnił, że to nie jest tak, że on nie chce dbać o siebie, jednak z uwagi na stan zdrowia i brak sił rzeczy, które wydobywał z szafy, bywały porozrzucane, a on sam nie umiał ich sprzątać, dlatego robiły to panie salowe. Po jakimś czasie założono mu kłódkę na drzwi szafy i kluczem dysponował personel, który według własnego uznania wydawał garderobę do przebrania. Słowa salowej okazały się sygnałem, że w DPS nie wszystko funkcjonuje tak, jak powinno.

Wolontariuszka prowadząca fizjoterapię była traktowana podobnie jak Pani

196 Kowalska i wobec niej także stosowano pewne formy wywierania presji. Będąc 
wolontariuszką nie miała obowiązku pracy w wymiarze ośmiu godzin dziennie. W praktyce wyglądało to $\mathrm{w}$ ten sposób, że obarczano ją również obowiązkami opiekuna osoby, z którą prowadziła fizjoterapię, co niejednokrotnie skutkowało zaniedbaniem terapii pozostałych osób, z którymi rozpoczęła współpracę. Dodajmy także, że i my, zaczynając praktyki, mieliśmy przydzielone osoby, które mamy odwiedzać. Pracownik socjalny pozostawił nam swobodę wyboru pensjonariuszy, uprzednio oprowadzając nas po pokojach i przedstawiając każdemu z mieszkańców. Kilkukrotnie okazało się, że potrzeby mieszkańców zostają zepchnięte na margines, a my byliśmy wysyłani przez Panią Nowak do ogrodu, gdzie mieliśmy zajmować się czyszczeniem ławek zabrudzonych ptasimi odchodami. Odbywało się to na oczach mieszkańców, personelu sprzątającego, a nasza uwaga, że być może warto by było porozmawiać z Panią Dyrektor o zakresie kompetencji, jakie mamy, została skwitowana słowami: ,...lepiej dyrekcji nie zawracać głowy takimi rzeczami”. Jak się wkrótce okazało, miała to być dla nas kara za „przesiadywanie u mieszkańców i picie kawy".

Przypadki utrudniania Pani Kowalskiej realizacji obowiązków służbowych nie były incydentalne. Wraz z wydłużającym się czasem wolontariatu mieliśmy okazję obserwować aktywność seniorów na zajęciach terapeutycznych i poznać elementy rozmaitych form terapii. Odbywało się to w porozumieniu z dyrekcją, która wyraziła zgodę na prowadzenie tego typu działań. W rozmowie mieszkańcy bardzo często podkreślali wartość spotkań, odczuwali poprawę swej koordynacji ruchowej oraz - co w ich opinii było wartością największą — podkreślali znaczenie atmosfery towarzyszącej zajęciom. Zgromadzenie osób w jednym pomieszczeniu, wytyczenie im celów nie tylko dawało możliwość aktywizacji czy pokazania wartości tego, co robią (prace były wywieszane w głównym holu), ale także budowało komfort psychologiczny, zaufanie i świadomość, że jest ktoś, komu zależy na ich losie i na tym, aby nie byli pozostawieni sami sobie w miejscu, w którym tak łatwo popaść w melancholię, odczuwać samotność. Gdy zbliżała się godzina 10.30, czyli pora rozpoczęcia zajęć, Pani Kowalska nie mogła ich spokojnie realizować z powodu nieustannych telefonów wzywających ją do biblioteki czy do pani kierownik, czy to do jej współpracowników, gdyż ,natychmiast była potrzebna w pokoju i w tej chwili powinna się zjawić”. Późną jesienią, właśnie w godzinach przedpołudniowych, zadzwoniła Pani Nowak z poleceniem dla uczestników zajęć, ,aby szybko zejść na dół i w przeciągu pięciu minut ustawić się na dworze, bo będą robione zdjęcia do udostępniania na stronie internetowej". Nie tylko nas współpracujących dotknęła ta sytuacja, lecz przede wszystkim mieszkańców, którzy byli w trakcie zajęć, ubrudzeni klejem, farbami, ubrani w szlafroki, koszulki. Wymóg postawiony w ten sposób wprowadził ogromny chaos, bo przecież każdy z seniorów chciałby się przebrać, aby na zdjęciu wyglądać korzystnie. Nie zwlekając wszyscy udaliśmy się przed wejście do budynku, gdzie seniorzy byli ustawiani do fotografii. Zmarznięci dopytywali co chwila, kiedy nadejdzie koniec, bo chcieliby wrócić na zajęcia. Po 40 minutach grupa wróciła do budynku, a wtedy okazało się, że były osoby, które dopiero zaczęły schodzić na zdjęcia i którym z przykrością musieliśmy powiedzieć, że się spóźniły. Dodajmy na koniec, że żadna fotografia nie znalazła się później na stronie internetowej. 
Nie pierwszy raz mieszkańcy przekazywali po tym incydencie informacje o swoim samopoczuciu. Docierające do nas informacje o lekceważeniu potrzeb seniorów były nagminne i powtarzane podczas okazjonalnych spotkań, takich jak coroczny piknik z okazji otwarcia DPS, wigilia, wieczór sylwestrowy. Pytania mieszkańców: „Kochani, dla kogo tak naprawdę to jest?”, „Czy ktoś się nami przejmuje?”, nas, wolontariuszy, wprawiały w zakłopotanie, a w kontekście oceny funkcjonowania placówki nasuwały niepochlebne wnioski. Poczucie osób starszych, że „są to imprezy przede wszystkim dla radnych i na pokaz”, znajdowało potwierdzenie w naszych doświadczeniach. Jako powiernicy wszelkich problemów stykaliśmy się bezpośrednio z tym, co seniorzy czują, jak widzą pewne sytuacje i w jaki sposób dotyka ich to, co dzieje się wśród personelu.

Prezentowany artykuł nie powstał po to, aby piętnować działalność DPS, w którym doszło do mobbingu i dezorganizacji pracy. Doświadczając tych mechanizmów w praktyce otrzymaliśmy pełny obraz zjawiska i jego zgubnych skutków dotykających nie tylko zainteresowanych stron. Omówienie przypadku nie byłoby możliwe bez wejścia w środowisko i zdobycia zaufania poszczególnych jednostek. Temat, choć bardzo trudny, pozwala zobaczyć, że placówki pomocowe nie są wolne od patologii tego typu, a to rodzi potrzebę uświadamiania w tym zakresie. Należy pamiętać, w jak trudnym położeniu jest ofiara, jakim działaniom ze strony oprawcy podlega, bo to jest punkt wyjścia do zidentyfikowania, a następnie do przeciwdziałania mobbingowi. Wszystkie negatywne elementy, które zdecydowaliśmy się opisać, nie mają funkcji stygmatu - decyzja o podzieleniu się wynikami obserwacji z czytelnikami ma za zadanie z jednej strony uczulić na tego typu zachowania, a $\mathrm{z}$ drugiej jeszcze bardziej uświadomić istotę i wagę problemu, któremu wiele różnych organizacji stawia czoła. Wyszliśmy z założenia, że jeżeli dzieje się coś złego, to należy o tym dyskutować nie po to, by okryć placówkę złą sławą, lecz po to, aby dla dobra poszczególnych jednostek i społeczeństwa w ogóle wskazywać konsekwencje takich działań i efektywnie im przeciwdziałać.

\section{Bibliografia}

Aaronson E., Wilson T.D., Alert R.M., 1997: Psychologia społeczna. Serce i umyst. Przekł. A. Bezwińska i in. Poznań: Wydawnictwo Zysk i S-ka.

Bańka A., 2000: Psychologia organizacji. Gdańsk: Gdańskie Wydawnictwo Psychologiczne.

Bechowska-Gebhardt A., Stalewski T., 2004: Mobbing. Patologia zarzadzania personelem. Warszawa: Wydawnictwo Difin SA.

Bugdol M., 2007: Gry i zachowania nieetyczne w organizacji. Warszawa: Difin.

Chirkowska-Smolak T., Grobelny J., red., 2015: Człowiek na rynku pracy. Wyzwania i zagrożenia. Kraków: Libron.

Chomczyński P., 2008: Mobbing w pracy z perspektywy interakcyjnej. Proces stawania się ofiara. Łódź: Wydawnictwo Uniwersytetu Łódzkiego. 
Dudkiewicz M., 2012: Jak nas widza, tak nas pisza — wizerunek publiczny pracowników socjalnych. W: M. Rymsza, red.: Pracownicy socjalni i praca socjalna w Polsce. Między stużba społeczna a urzędem. Instytut Spraw Publicznych.

Durniat K., 2012: Prewencja i przeciwdziałanie mobbingowi w polskich organizacjach. „Współczesne zarządzanie”, nr 4.

Frankfort-Nachmias Ch., Nachmias D., 2001: Metody badawcze w naukach spotecznych. Poznań: Zysk i S-ka.

Kowal J., 2011: Mobbing jako problem etyki w zarządzaniu. „Etyka w Życiu Gospodarczym", T. 14, nr 1.

Kozak S., 2009: Patologie w środowisku pracy. Zapobieganie i leczenie. Warszawa: Wydawnictwo Difin SA.

Krzyszkowski J., 2010: Między państwem opiekuńczym a opiekuńczym społeczeństwem. Determinanty funkcjonowania środowiskowej pomocy społecznej na poziomie lokalnym. Łódź: Wydawnictwo Uniwersytetu Łódzkiego.

Kurowska K., 2016: Mobbing jako patologiczne zjawisko w miejscu pracy. „Ekonomia i Zarządzanie. Zeszyty Naukowe", nr 1(1).

Leymann H., 1996: Mobbing: The Persecution au Travail. Paris: Seuil.

Marciniak J., 2011: Mobbing, dyskryminacja, molestowanie - zasady przeciwdziałania. Warszawa: A. Wolters Kluwer business.

Pasieczny J., 2012: Patologie organizacji w okresie kryzysu. „Prace i Materiały Wydziału Zarządzania Uniwersytetu Gdańskiego. Zarządzanie i Finanse”, nr 4/2.

Pospiszyl I., 1998: Przemoc w rodzinie. Warszawa: Wydawnictwa Szkolne i Pedagogiczne.

Silverman D., 2007: Interpretacja danych jakościowych. Warszawa: Wydawnictwo Naukowe PWN.

Stocki R., 2005: Patologie organizacji — diagnoza i interwencja. Kraków: Oficyna Ekonomiczna.

Szacki J., 2006: Historia myśli socjologicznej. Warszawa: Wydawnictwo Naukowe PWN. Sztompka P., 2010: Socjologia. Analiza społeczeństwa. Kraków: Wydawnictwo Znak.

Weber M., 2004: Racjonalność, władza, odczarowanie. Wybór, wstęp, przekład M. Holona. Poznań: Wydawnictwo Poznańskie.

Wojciszke B., 1991: Procesy oceniania ludzi. Poznań: Wydawnictwo Nakom.

Wyleżałek J., 2012: Mobbing uczelniany jako problem społeczny. Specyfika, uwarunkowania organizacyjne oraz konsekwencje przemocy w miejscu pracy na przykładzie szkół wyższych. Warszawa: Wydawnictwo SGGW. 